Article

\title{
Modern Housing Retrofit: Assessment of Upgrade Packages to EnerPHit Standard for 1940-1960 State Houses in Auckland
}

\author{
Paola Leardini ${ }^{\dagger, *}$ and Manfredo Manfredini ${ }^{\dagger}$ \\ School of Architecture and Planning, The University of Auckland, 26 Symonds Street, 1010 Auckland, \\ New Zealand; E-Mail: m.manfredini@auckland.ac.nz \\ $\dagger$ These authors contributed equally to this work. \\ * Author to whom correspondence should be addressed; E-Mail: p.leardini@auckland.ac.nz; \\ Tel.: +64-9-373-7599 (ext. 82142); Fax: +64-9-373-7694.
}

Academic Editor: George Baird

Received: 18 December 2014 / Accepted: 27 February 2015 / Published: 11 March 2015

\begin{abstract}
New Zealand state housing includes a significant portion of problematic buildings constructed after the public housing scheme launched in 1936. Most of these houses are still uninsulated, thus, cold, draughty, mouldy, and progressively decaying; however, as they are fundamental elements of the country's culture, society, and environment, and are built with good quality materials and sound construction, they are suitable candidates for effective energy upgrades. This paper presents findings of a study on problems and opportunities of retrofitting the state houses built between 1940 and 1960 in the Auckland region. It advocates strategic national policies and initiatives for retrofitting, based on more challenging performance thresholds. The research defines and virtually implements an incremental intervention strategy including different retrofit packages for a typical 1950s stand-alone house. Indoor and outdoor environmental parameters were monitored over a year, and data used to establish a base case for thermal simulation. The upgrade packages were then modelled to assess their impact on the house's thermal performance, comparing heating requirements and comfort of various insulation and ventilation options. The paper reports on effective ways of preserving the integrity of such a house, while improving its thermal performance to the EnerPHit standard, and discusses the benefits of introducing this holistic approach into New Zealand retrofit practice.
\end{abstract}


Keywords: New Zealand state house; energy retrofit; EnerPHit; Passive House Planning Package; stand-alone house

\section{Introduction}

According to the International Energy Agency, buildings are responsible for $32 \%$ of the total final energy consumption and around $40 \%$ of the primary energy consumption in most of its member countries [1]. The growing awareness of the impact of the built environment on energy security that started with the 1973 oil crisis has made building energy efficiency a common target of many national energy conservation policies. It also has produced a wide variety of analytical, certification and rating tools aimed at assessing and enhancing the energy performance of new buildings. The effect of these measures, though, has been limited, since these instruments only partially address the activities of renovation, repair and maintenance of existing buildings, which constitute a large part of construction activity in developed countries. An increased effort towards consistent inclusion of the existing stock in policies and programmes for the improvement of energy efficiency is crucial to achieve tangible savings in building-related energy consumption and $\mathrm{CO}_{2}$ emission reduction. This is particularly relevant, as in many urban transformations retrofitting is often more effective than demolition and reconstruction in both economic and environmental terms as demonstrated by studies using Life Cycle Analysis [2]. Further benefits need to be accounted when the retrofit involves buildings with historic or cultural value: heritage retrofit not only contributes to the development of local culture-enhancing the quality of the urban environment while retaining its character and heritage-but also supports local economies, since this kind of retrofit requires a wide array of skilled labour on site. Overall, the conservation of existing buildings positively influences local communities, promoting resilient and sustainable urban living patterns.

In New Zealand, retrofit activity has proved to be non-cyclical (while new building construction is characterized by sharp highs and lows) [3] and has exceeded new construction, especially since the global financial crisis. According to Building Research Association New Zealand (BRANZ) already in 2008 alterations and additions (including approximately 33,000 residential consents [4]) represented about one-third the total value of new dwellings. This activity is expected to increase, due to the significant ageing of the New Zealand housing stock and the need for earthquake strengthening and other urgent maintenance interventions. Current residential buildings will constitute the largest portion of the country's housing stock in coming decades [5,6]: BRANZ estimates $85 \%$ will be still in use by 2025 [7]. However, most houses do not have sufficient insulation to provide comfortable living: about 65\% were built before 1978, when mandatory insulation was first introduced with the standard NZS 4218P: 1977 Minimum Thermal Insulation Requirements for Residential Buildings. Research found that even when upgraded according to current local practice, average winter indoor air temperatures are extremely low [8], and frequently fall below the limit of $18{ }^{\circ} \mathrm{C}$ recommended by the World Health Organisation [9]. As housing is internationally recognised as a key determinant of health and the country has one of the highest incidences of asthma worldwide (with low socio-economic groups disproportionately affected [10]), the New Zealand government has committed to improve the nation's 
health introducing relevant policies, as well as subsidies to enhance the performance of houses, particularly those of low-income households. The state housing stock includes a significant portion of problematic houses, built in the 1940s and 1950s under the government-funded social housing scheme introduced in 1936. Most of these are managed by Housing New Zealand Corporation (HNZC), the largest public landlord in the country, which recently focused on upgrading its housing stock-especially in Auckland where $43 \%$ of state housing is concentrated [11]. Historically, due to the mild climate of this region, the extent of this problem and the urgency of actions required have been often underestimated. However, the socio-economic relevance of these interventions was confirmed by studies on the relationship between the density of state housing and area deprivation status [12] that highlight the key role of the house in improving living conditions of disadvantaged social groups [13].

This paper presents the most recent results of a study undertaken at the University of Auckland to assess the performance of pre-1978 low density state housing in the Auckland region with regard to occupant health and comfort, as well as energy efficiency, and to identify better retrofit strategies and practices. It aims to delineate a path to "nearly zero" energy housing-borrowing goals and definition of the recent European Directive 2010/31/EU (EPBD recast). The research focuses on the 1940 to 1960 housing cohort, one of the most suitable for effective renovation due to its pre-eminence and homogeneous composition [14]. This cohort is mainly composed of suburban detached or semi-detached houses occupied by low-income households.

This paper briefly discusses the social and cultural value of this house type. Then, it critically reviews past and current retrofit practice, highlighting the limits of its market-driven approach, and advocates future strategic national policies and initiatives for retrofitting, based on more challenging performance thresholds. The paper reports on effective ways of preserving the integrity of a typical stand-alone state house in Auckland, while improving its thermal performance to the EnerPHit Standard [15], and discusses the benefits of introducing this holistic approach into New Zealand retrofit practice.

\section{Intangible Cultural Heritage Value of Mid-Century State-Supported Housing}

Mid-twentieth century state-supported housing is an important part of New Zealand's cultural patrimony, reflecting the fundamental values, knowledge and techniques that characterise the transition of the country to the post-colonial era. These houses and settlements, with associated physical and social infrastructures, not only produced a significant portion of the country's urban fabric, but constituted the benchmark for the overall production of houses and urban extensions, both in terms of spatial patterns and technological solutions (Figure 1).

Today, they distinctively emerge in the contemporary city, since their material consistency and experiential dimensions express an approach to the construction of the living environment that substantially differs from those of antecedent and following periods. Beyond the peculiar morphological features that make these houses immediately recognisable (such as the $32^{\circ}$ pitch roof and the standard windows placed just under the soffit), what marks their difference is their consistent sets of conception, representations and practices. Their paradigm still actively engages contemporary life, to some even representing the main reference and framework for both their activity and identity [16]. The numerous projects completed with state support through direct intervention (by the Housing Division of the 
Ministry of Works) or financial means (through the State Advances Corporation), constitute a diffuse presence in contemporary New Zealand cities [17]. They oppose the progressive fragmentation of the current city with the integration model framed in the social welfare politic introduced in 1935 by the first Labour government. This model becomes more and more important in the current urban reorganisation towards sustainable environments for resilient communities, showing its efficacy through the vitality of its environments. Indeed, it successfully elaborates subtle articulations of fundamental integrative elements concerning the reciprocal relations between private and public spheres, urban and natural environments, senses of independence and belonging, and community and multitude. These forms of integration are testimony to the modern re-interpretation of the extraordinary effort of colonial New Zealand society to concretise the shared "happy dream of the imagination" envisioned by Edward Gibbon Wakefield in its theory of colonisation [18]. Its mid-century revision underpinned the development of a prosaic formulation of an "overall culture of family and home" [17] (p. 204); a concrete utopia deployed through a narrative structured around four key elements: family life, bucolic existence, cohesive community and diversity. On the one hand, the idea of providing the family with a retreat in the domestic idyll associated with the reconnection of urban and natural life further elaborated the garden suburb model derived from the British garden city that was introduced in New Zealand in 1919. It is worth noting that this model has become the desired norm of New Zealanders, orienting housing choices and preventing the development of denser urban forms, notwithstanding urban sprawl issues that have been recognised since the 1950s [19]. On the other hand, the support for individual paths of "emancipation through social identification" and the recognition of "originality in self-expression" led to the establishment of habitats of multiplicity where integration was to achieve through the manifestation of difference.

The construction of diversified domestic landscapes through the adoption of the traditional type of the detached home, confirmed as a fundamental hinge of people's life, was further developed by combining individuality with the latest functionalist precepts of rational layout and access to sun, air and nature. Coherent responses to specific environments, conceptions and practices were implemented with an idiosyncratic range of spatialisation forms that were modulated through an extremely high number of patterns, types and variations, and resulted in the creation of never repeated places and landscapes. The preliminary phase of the research presented in this paper explored the extent of this phenomenon through a quantitative analysis of the Auckland case. It showed how the high house type number (exceeding 12,000) corresponds to a very low average repetition (below five occurrences) of realisations for each type [20].

The rich and diverse patrimony embedded in those domestic architectures, in families and communities of their inhabitants and in their physical and cultural landscapes, is an irreplaceable legacy of a foundational milestone of the construction of New Zealand society. As such, it cannot be preserved selectively: its multiplicity and diversity represent one of its highest achievements. It is a living representation of the great modern effort to construct a concrete and effective collective model of social, cultural and physical progress. Having been recognised by Nikolaus Pevsner as "the most ingratiating chaos one can imagine" [21], the highest challenge for the preservation of its integrity is to develop appropriate analyses and interpretations of each and every individual condition concerning people, territories and signs. 


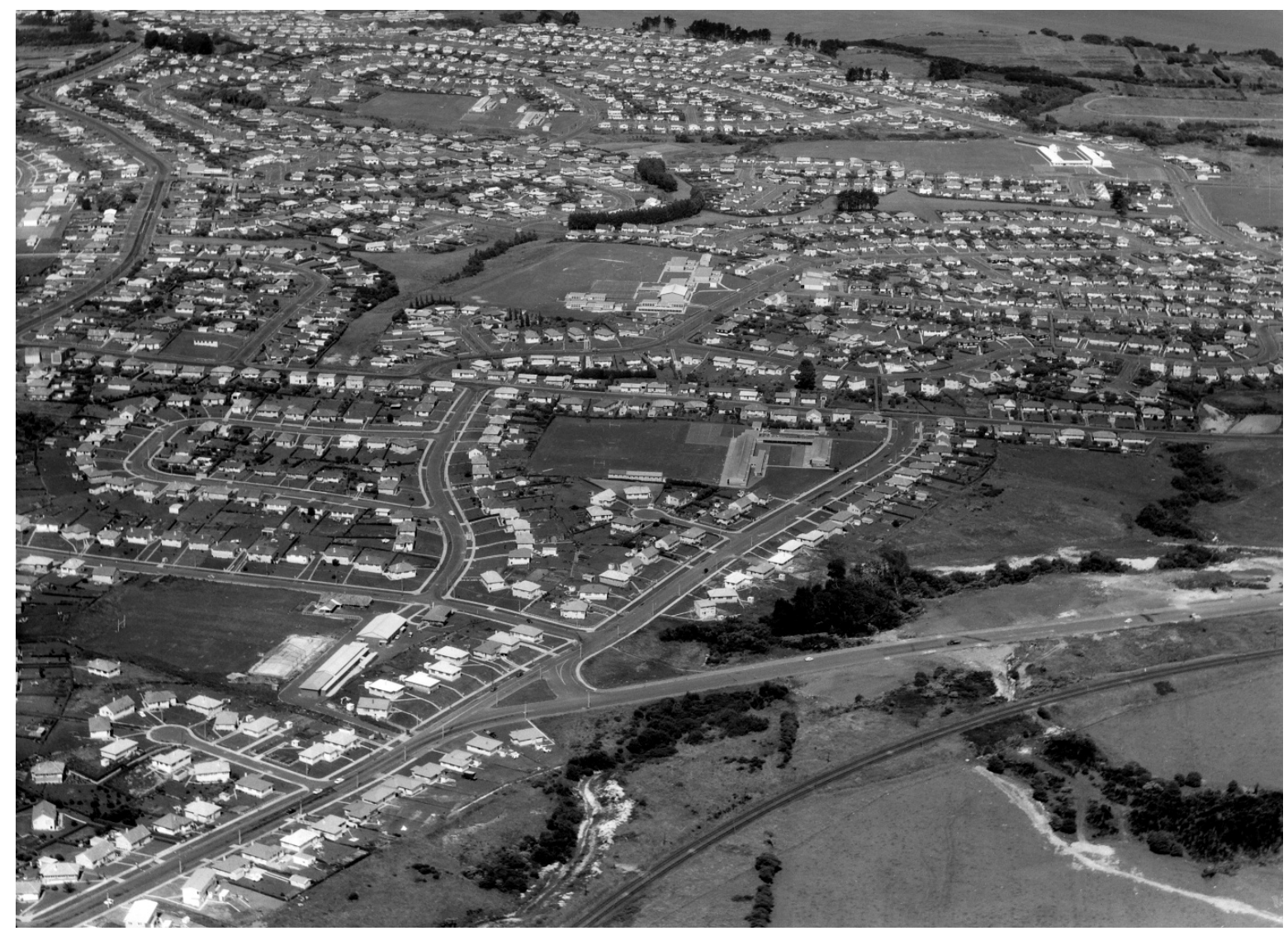

Figure 1. Glen Innes, Auckland, 12 December 1961. Whites Aviation Ltd.: Photographs. Aerial photograph of the northern part of the Tamaki state house scheme. The pilot project house is featured in the bottom left side of the image. Source: Alexander Turnbull Library, Wellington, New Zealand. Ref: WA-56411-F. http://natlib.govt.nz/records/22856887.

\section{New Zealand Housing Retrofit}

According to the latest OECD assessment on people's wellbeing [22], New Zealand ranks as the second highest country for housing expenses of households: on average above one quarter of disposable income. Accounting for $16.3 \%$ of total household income, the total costs of housing increased rapidly in 2013/14 [23], worsening the problem of affordability. This particularly affects Auckland, the largest city of the country and one of the five most unaffordable major markets worldwide [24]. Without reduction of the housing shortage, this situation cannot be eased, but is expected to worsen: the growing difference between demand and supply cannot be reversed, due to the limited capacity of the construction industry [25]. With this structural scarcity and a market dominated by investors - who in 2014 won more than $45 \%$ of all sales [26] — the existing housing stock is subject to intensive exploitation, resulting in an emphasis on profitability through short term capital gains. This draws attention away from running costs and building operating efficiency, further exacerbating problems arising from poor building maintenance - especially critical for those houses already unable to guarantee comfortable and healthy living conditions.

Problems affecting current New Zealand housing stock are well documented, but there is still little information available on their specific extent. The largest source of data currently accessible is a series of House Conditions Surveys conducted on representative samples by BRANZ from 1994 to 2010. 
They show that a large portion of the existing stock offers substandard living conditions, due to lack of maintenance: only $40 \%$ of the sample assessed in the 2010 survey, including new construction, was considered "well maintained," while $25 \%$ had defects to be urgently addressed [27]. The 2010 survey shows a high percentage of homes with some form of insulation, mainly in the roof cavity; but still, $52 \%$ of both new and old construction had no wall insulation and $45 \%$ of accessible suspended floors remained un-insulated. Lack of insulation appears to be a feature of most pre-1978 houses, despite different policies and programmes implemented within the framework of National Energy Efficiency and Conservation Strategies [28,29].

The critical condition of older houses also resulted from the limited effects on existing buildings of the New Zealand Building Code (NZBC), which includes stringent requirements for new houses insulation but offers little guidance for renovations. The provisions for energy performance and comfort of the NZBC are included in Clause H1-Energy Efficiency [30] and Clause G5-Interior Environment [31]. The latter, despite introducing a minimum internal temperature limit $\left(16^{\circ} \mathrm{C}\right)$ for old people's homes and early childhood centres, has no quantitative requirements for other residential buildings. Conversely, Clause H1 fixes the maximum building heating energy consumption by establishing the Building Performance Index (BPI), a thermal performance measure calculated as heating energy divided by the product of heating degrees total, floor area and total wall area. The recently refined BPI, though effectively requiring houses to use less heating energy than before, still allows rather low R-values for building envelopes across all New Zealand regional climates, especially inadequate in the colder areas of the country [32].

\subsection{Costs and Benefits of Housing Retrofit}

While general awareness about needs and benefits of improving living conditions has increased, it seldom translates into adequate energy retrofit actions. This is mainly because, as capital gain is the primary driver for home renovations, the emphasis on short-term financial return does not appropriately cope with long-term sustainability principles. The fact that New Zealand still enjoys some of the lowest power tariffs in the world often challenges the acceptance of future proof retrofitting plans. Page [33] found that basic efficiency measures, including ceiling and under-floor insulation, are considered worthwhile from a cost-benefit viewpoint in all locations in New Zealand; enhanced solutions though, such as wall insulation and double glazing, are not considered cost-effective when compared to the installation of heat-pumps and solid fuel burners, especially in the milder Auckland region. This approach, disregarding environmental concerns and predicted energy shortage, has supported current retrofitting practice and policies, which make basic interventions on the building envelope and heating devices, instead of addressing a comprehensive requalification of the older building stock. However, it does not consider the "non-energy benefits" of efficiency upgrade measures: comfort levels are not given as an "invariable" but included in the cost-benefit equation with the same value of energy savings. This economically driven approach has been criticised by the social scientist Philippa Howden-Chapman: focusing on positive effects of adequate house insulation on reduction of health inequality, she highlighted the relation between cold and damp houses, and mould growth, which is a trigger for respiratory illnesses [13]. Her findings showed how health costs of substandard living conditions are often paid by the weakest social groups. This study, considering predominantly 
low-income communities in New Zealand, concluded that retrofitting insulation in existing homes led to significantly warmer and drier living environments, which resulted in improved health and reduced days off school and work. She also proposed a cost-benefit analysis [34] that included health gains, energy and environmental savings, and suggested that the monetary value of improving housing quality is "compelling", as its total benefits equal to "one and a half to two times the magnitude of the cost of retrofitting insulation". She found that $61 \%$ of the total benefits were health sector gains, so her research confirms the social relevance of retrofitting and the need of filling the gap of research on cost-effectiveness of regulatory requirements to eventually guide their improvement.

\subsection{Retrofit Programmes}

Pre-1978 housing stock in New Zealand does not present significant typological differences between public and privately owned dwellings. Although quite varied, state houses and most private houses were mainly single or double-storey detached buildings, generally with small square or rectangular floor plans, with hipped or gabled roofs covered with tiles, asbestos-cement shingles or corrugated sheets. The envelope, largely timber-framed construction, was realised using a limited selection of cladding materials (timber weatherboard, brick veneer, stucco or asbestos-cement cladding) and no insulation [35]. These houses though, were very progressive compared to the bungalows and villas that preceded them. Instead of the villa layout, strictly designed in relation to the main street and disregarding cardinal directions, the new types were usually orientated to the north to allow maximum sun penetration into the main interior living areas in winter, and fitted with eaves for protection from the summer heat. Windows were larger to increase sunlight and fresh air, which were deemed very important to avoid the recent outbreak of tuberculosis and diphtheria: the window area was indeed sized to be $15 \%$ of the floor area of the room, with half of the windows openable for ventilation [36].

The innovative planning and robust construction of early state housing types, however, did not prevent them being cold and draughty: within a few years from construction, mould was discovered in $57 \%$ of the houses built from the early 1940s [37,38]. Since these and successive findings of research to investigate the correlation between insulation, ventilation, and healthy interiors did not substantiate in any housing improvement, most of those houses that have not been renovated still present the same issues. Indeed, compared to privately owned houses, the maintenance level of state-owned rental properties has often been lower for basic budget constraints, and included minimal upgrade interventions over the time.

After decades without maintenance, in 2001 the government's National Energy Efficiency and Conservation Strategy [28] set up the political and financial framework to support a major energy retrofit programme, providing a platform to extend funding for pre-1978 home insulation retrofits, including state housing stock, around the country. The programme aimed to upgrade two thirds of the stock with ceiling insulation, aluminium foil below suspended floors, hot water cylinder insulation and draught stoppers. Given the magnitude of the programme, the University of Otago was commissioned to monitor results of the upgrade process by measuring energy consumption and indoor thermal environment of a sample of 100 state houses in Dunedin [39]. Findings of this study seriously challenged the efficacy of the retrofit programme, revealing apparent limits of retrofitting to ceilings and floors only. In the South Island, this produced only small temperature increases that were 
insufficient to guarantee healthy indoor environments. Budget constraints have downsized public upgrade programmes. These, however, should not be evaluated in terms of simple payback times. Instead, social benefits must become the real driver, as affirmed by the successful initiative started by HNZC in the Auckland region in 2000: the Healthy Housing Programme, a comprehensive scheme aimed to reduce the risk of infectious diseases related to overcrowding. Beside health and social interventions to identify families with health needs and provide social services accordingly, the scheme included housing retrofitting intervention to address cold, mould and ventilation issues [40].

In 2009, the Energy Efficiency and Conservation Authority made a further attempt to overcome the poor energy performance of a still significant part of the housing stock, launching the Warm Up New Zealand: Heat Smart Programme. Its scope was to subsidise costs of retrofitting insulation and installation of clean heating for houses built before 2000. Although this programme proved beneficial, in particular to health [41], the subsidies are not subject to the achievement of any specific performance level (under the assumption that any amount of insulation installed represents an appreciable improvement), so its efficacy is difficult to assess and its results are questionable. Furthermore, it has been observed that long-term effects can be challenged, considering that basic retrofit interventions may reduce future energy savings, i.e., "the potential revenues of an energy efficiency investment [as] future amendments to improve quality are very improbable because they will not pay back, thus impeding future sustainable development" [42]. This highlights the need for a more holistic retrofitting approach, addressing wall insulation, airtightness, and ventilation.

\subsection{From Common Practice to EnerPHit Standard}

In recent years, the growing market pressure due to housing shortage and speculative investments in the real estate sector have made old houses in need of renovation a valuable target. In this context, interventions are usually market-driven and mainly concentrated on spatial layout improvements, with bathroom and kitchen upgrades being the most effective way to achieve short-term paybacks; there is very little concern for thermal comfort, indoor air quality and airtightness. Building consents must be lodged only when the improvements require substantial alterations of the existing envelope, and for new additions, which must comply with the criteria and energy performance requirements of the Code. Underfloor and roof insulation retrofits are exempt from building consent according to Schedule 1 of the New Zealand Building Act. However, retrofitting insulation into a wall cavity either requires a building consent or specific approval from the authority, as the impact on the existing building can be potentially problematic (e.g., for moisture accumulation, timber framing and cladding durability, fire and electrical safety). Despite that, thermal resistance of retrofitted walls does not need to comply with the Building Code Clause H1-Energy Efficiency [30]. This set of rules accepts that the partial and cosmetic retrofit interventions mentioned above are executed without considering housing performance and indoor comfort matters [43].

Even the most forward-thinking examples of retrofitting simply aim at improving the energy performance of buildings to match minimum requirements of the current NZBC, which do not guarantee acceptable indoor air quality and comfort. Indeed, concerning current Code requirements, a recent study undertaken at the University of Auckland [44] focusing on New Zealand houses built after 2000, showed that thermal comfort in Code-compliant houses is generally below the acceptable 
threshold defined by international standards [45]. Measured air-leakage rates appeared high compared to both European houses and international guidelines, and yet the resulting indoor air quality was relatively poor. This is also consequent to the fact that neither the NZBC nor the New Zealand ventilation standards set any airtightness target for residential buildings that rely on natural ventilation. NZBC Clause H1-Energy Efficiency states that the airtightness of the building envelope has to be taken into account, but does not define any specific threshold. Clause G4-Ventilation [46] only requires openable areas (window and doors) to be more than $5 \%$ of the floor area for air quality and summer cooling, relying on the New Zealand tradition of satisfying ventilation needs with background infiltration, i.e., uncontrolled access of outdoor air into the building through leaks in the envelope. Without any Code requirement, retrofitting practice is not compelled to address airtightness, especially given the additional cost of achieving acceptable performance using conventional construction methods. However, this exposes existing houses to new risks, as shown by recent research on the effects of retrofitting insulation according to common practice (i.e., without a ventilated air cavity or a vapour control layer), which confirmed the possibility of formation of interstitial condensation and related moisture problems [47]. This not only suggests that the Building Code is in need of more detailed identification of benchmarks to promote healthy and energy efficient houses, but also that retrofitting practice must set higher goals to be effective.

The depicted scenario of retrofitting practice demands a new set of upgrade strategies aiming to more ambitious performance targets. Based on energy efficiency and comfort, the performance-based Passive House Standard [48] seems to offer effective answers to the identified issues. Developed in Germany in the early 1990s by Professors Bo Adamson and Wolfgang Feist, this is the fastest growing energy performance standard in the world, with over 30,000 buildings realised to date. Its strengths lie in the simple, non-prescriptive approach, based on the excellent thermal performance and airtightness of the building envelope. According to the Passivhaus Institut (PHI), "a Passivhaus is a building for which thermal comfort can be achieved solely by post-heating or post-cooling of the fresh air mass, which is required to achieve sufficient indoor air quality conditions-without the need for additional recirculation of air" [49]. A traditional heating system is no longer essential, due to reduced heating needs. The other important feature is its excellent indoor air quality, achieved by reducing the air infiltration rates and supplying filtered fresh air that can be post heated by a mechanical ventilation unit with heat recovery (MVHR).

The standard was first officially introduced to New Zealand in 2011, with the launch of Passive House Institute New Zealand (PHINZ) and the construction of the first Passive House in Auckland - certified the following year. Since then Passive Houses have spread throughout the country, especially in the North Island. In the retrofitting sector, however, the standard has been widely disregarded, due to its presumed high costs. Indeed, it can be technically and economically difficult to achieve the requirements of the standard in old residential buildings, due to unavoidable thermal bridges, constraints with insulation installation and air-leakage issues. Considering these aspects, in 2010 PHI introduced the EnerPHit standard for energy retrofits with a certification method based on listed Passive House components. These however, are available for cool-temperate climates only. To overcome this limitation, PHI started a research process to define international component requirements that can serve as the basis for international EnerPHit criteria [50]. The requirements are the result of an economic optimization process applied to a simplified set of seven climate zones around the globe. 
PHI also developed an alternative certification method for building retrofit based on performance requirements. These are looser than those for new construction, with maximum space heating and cooling demand of $25 \mathrm{kWh} /\left(\mathrm{m}^{2} \mathrm{a}\right)$ and a limit value of the envelope air permeability rate $n_{50}<1.0 \mathrm{~h}^{-1}$ - that is expressed as the ratio between the air leakage rate at 50 Pascal air pressure and the total volume of air in cubic metres. While the airtightness limit will remain valid for all climate zones of the future international EnerPHit standard, heating and cooling demand will be tuned to the different zones: from $30-35 \mathrm{kWh} /\left(\mathrm{m}^{2} \mathrm{a}\right)$ in cold and artic climates to $15-20 \mathrm{kWh} /\left(\mathrm{m}^{2} \mathrm{a}\right)$ in warm and warm-temperate climates.

\section{Research Methodology}

This paper presents the most recent findings of a long-term study carried out at the University of Auckland on eco-retrofitting of pre-1978 state housing in Auckland. This study proposes and tests a new holistic approach to improve upon the sheer economic cost-benefit path driving the majority of common retrofit practices, which disregard social costs (in particular the ones related to health and environment issues highlighted above) and socio-cultural matters. Consistent with sustainable development principles and aiming to preserve the social, cultural and material integrity of the mid-twentieth century housing stock in New Zealand, the proposed approach sets specific criteria for its upgrade. It draws upon a comprehensive investigation of social, environmental and architectural aspects, as well as local and international retrofitting best practices. On the basis of the successful implementation in New Zealand of the Passive House standard for new construction, in the Auckland region, the research proposes to adopt the EnerPHit energy efficiency and comfort targets for retrofitting in warm-temperate climates. The applicability of the standard is tested through the development of a pilot project that includes an intervention strategy articulated on four incremental phases.

Overall, the research included the following consecutive phases: (1) Collection, systematization and analysis of documents and information, and subsequent definition of a type stock pool of pre-1978 low density state houses; (2) Selection and analysis of representative case-studies in Auckland; (3) Comparative evaluation and adaptation to New Zealand of internationally recognized diagnostic and measurement protocols, and building performance standards; (4) Identification and documentation of a pilot project and two control cases including measured drawings, stratigraphic and 3D models, diagnostic survey (building pathologies, Blower Door test, thermography, stratigraphic inspection and analysis of structural and functional inadequacies) and occupants' interviews; (5) Environmental parameters' measurement campaign of the pilot project and the two control cases; (6) Development of an intervention strategy and related retrofit packages with assessment through thermal simulation (comparing annual heating requirements of various insulation and ventilation options) for a pilot-project in Auckland.

While the results of phases $1-5$ have already been published [20,51], this paper focuses on the last research phase concerning the definition and evaluation of the intervention strategy and its phased incremental retrofit packages.

\subsection{Pilot Project and Measurement Campaign}

The pilot project concerns a representative three-bedroom state house. It was built according to one of the most common types (6/1163) developed by the Department of Housing Construction in 1940s, as part of the large Tamaki state house scheme in the outer Auckland suburb of Glen Innes (Figure 2). 
It is a single story building of $93 \mathrm{~m}^{2}$ on sloping ground with a west-oriented living room. Although this house passed into private ownership, it has retained the original layout and features. The typical timber frame construction, enclosed by weatherboard cladding and internal plasterboard lining, has a tiled roof and a suspended (carpeted) timber floor. It sits on perimeter concrete walls that define a basement space partially accessible due to the sloping terrain (Figure 3). Originally without insulation, a few years ago the house was refurbished with the addition of polyester blankets over the ceiling and under the floor, between joists. Lying in a prominent position that benefits from good solar access, it has a well-ventilated basement space, which makes it very dry in comparison to the majority of similar residential buildings of the neighbourhood (Figure 4).

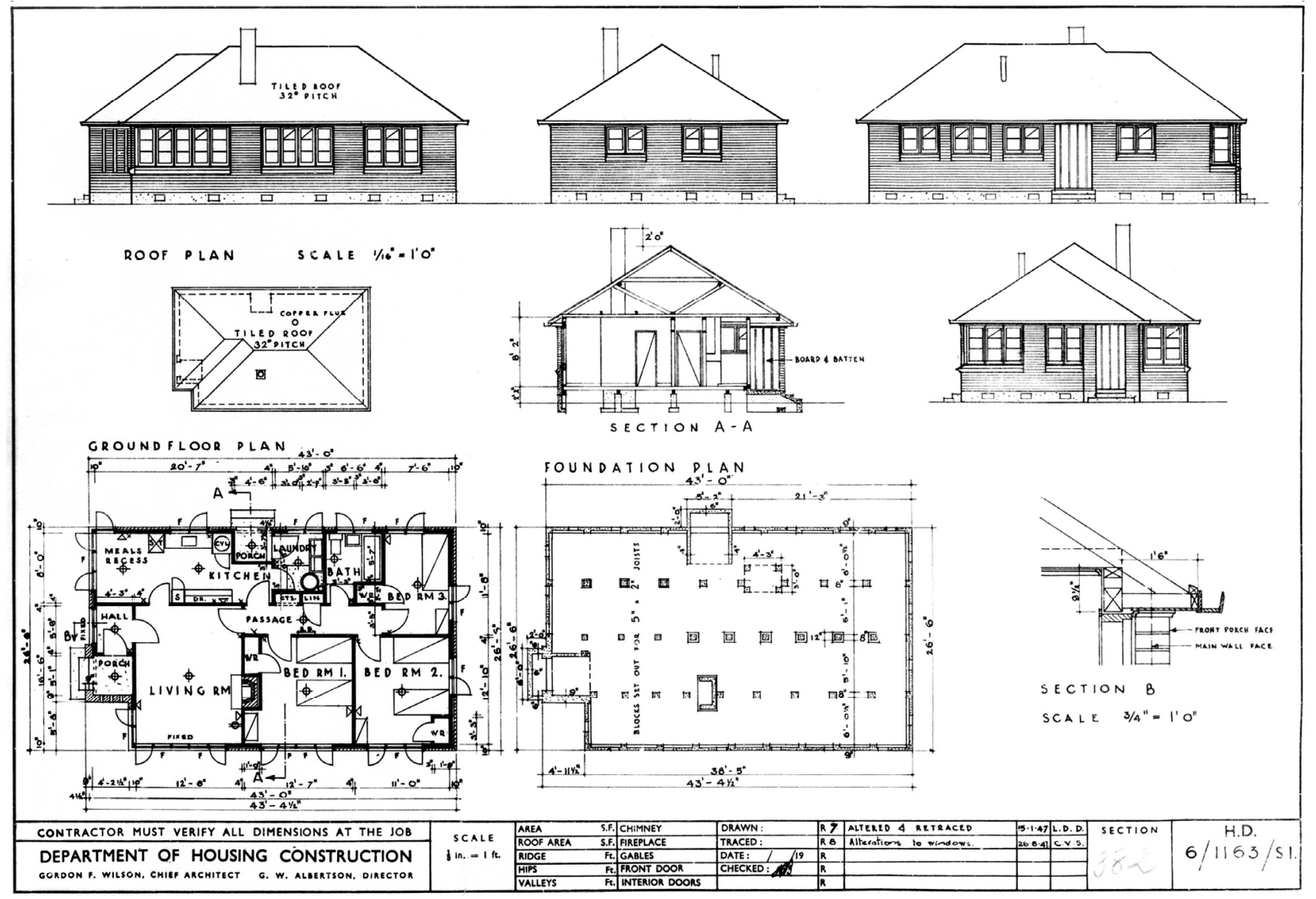

Figure 2. Original documentation of the Department of Housing Construction for the house type 6/1163 of 1947 . The house selected for the pilot project is its wooden variant for sloping ground. Ref: Source: Housing New Zealand Auckland Regional Office, Floor plans and details for standard houses, naval housing, pre-cuts, demonstration flats, star flats and point flats. Ref: Q12_47, BBKD 10559 Box1 (Archives New Zealand/Te Rua Mahara o te Kāwanatanga, Auckland Regional Office). 


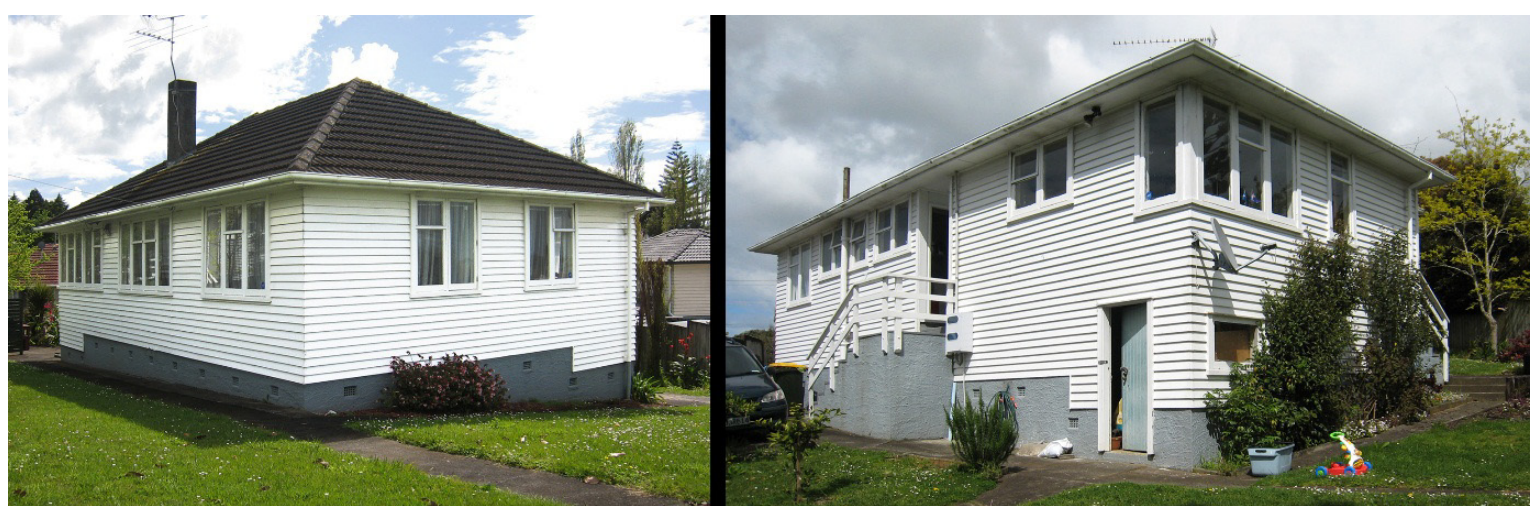

Figure 3. South-west (street side) and north-east (backyard side) views of the pilot project house in 2012.

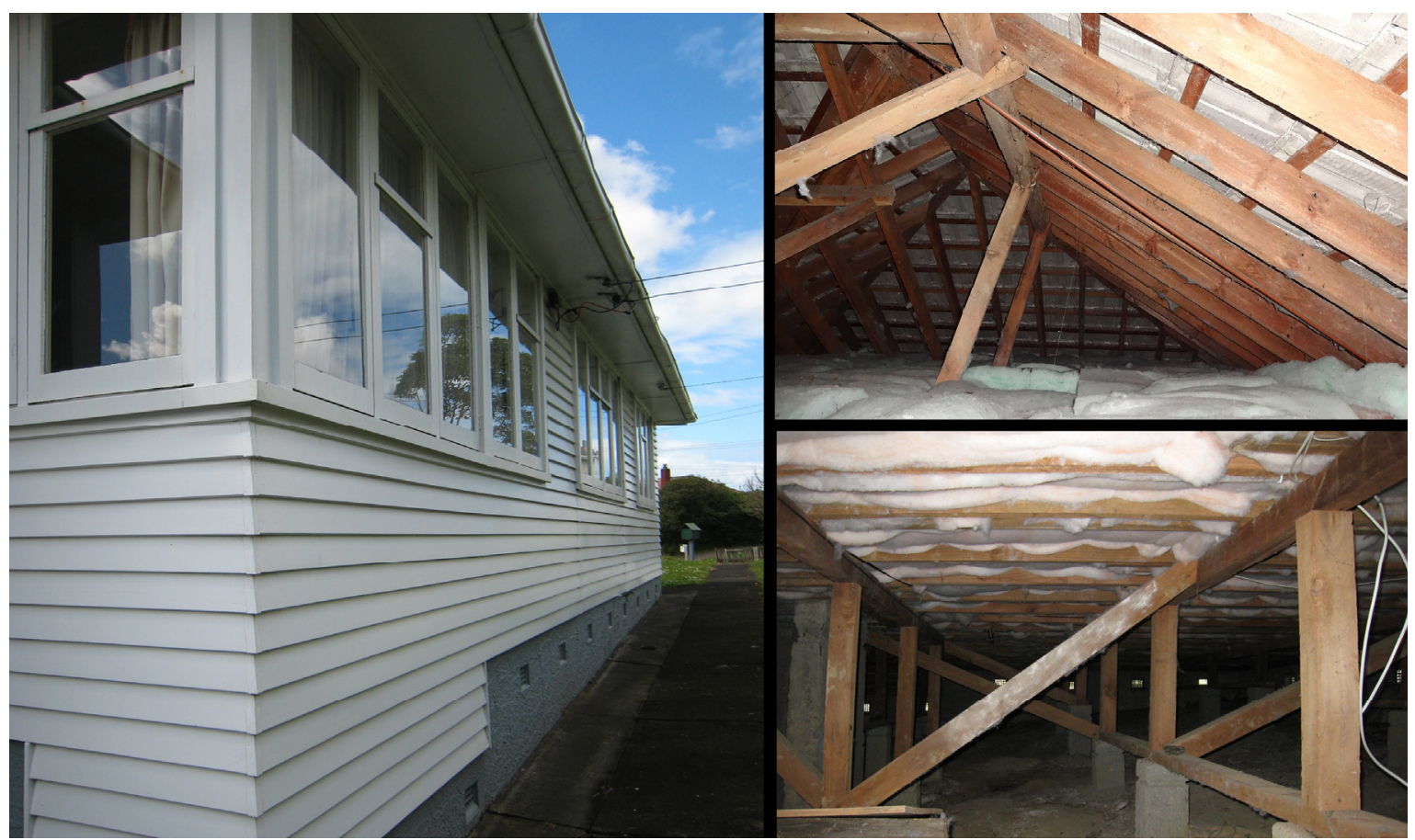

Figure 4. North-west facades, hipped roof cavity (timber rafters with concrete tiles and polyester insulation) and basement cavity (jack studs, sleepers and bracing struts on concrete blocks supporting floor joists with polyester insulation in-between) of the pilot project house in 2012.

In 2012, a measurement campaign of pre-retrofitting indoor and outdoor environmental parameters was carried out to provide empirical data. It was used to validate the simulation model of the various energy upgrade packages and provide a reliable basis to the quantification of potential energy savings and indoor comfort improvements. It included one year of continuous data collection (from January to December) of indoor and outdoor environmental parameters using data loggers (iButton and HOBO) for measuring air temperature, relative humidity and $\mathrm{CO}_{2}$, and energy metering systems (smart meters). Weather conditions (air temperature, relative humidity, wind speed and direction, and global solar radiation) were recorded using hourly data provided by the National Institute of Water and Atmospheric Research. 


\subsection{Intervention Strategy}

The strategy adopted to achieve the defined primary social and cultural objectives of the research proposes the conservation and sustainable development of peoples' habitats with particular regard to the integrity of the existing buildings and their physical environment. It includes the definition of a set of actions, framed in participatory processes both in the planning and implementation phases, to allow residents to remain in place, consolidating their communities and sense of ownership (only strictly necessary short-term relocations are foreseen). These actions aim to preserve the material patrimony and aesthetic character of the houses, including their overall building structure, spatial organisation and decorative framework.

Economic concerns have also been fundamental drivers of the strategy and its implementation through incremental retrofit packages, particularly aiming to provide flexible investment options and minimise costs of components, material, procurement and labour. The proposed phasing comprises a four-step series of coherent, effective, discrete and independent retrofit packages, respectively concerning the improvement of thermal performance and airtightness of ceiling (PH-S1), flooring (PH-S2), external walls (PH-S3), as well as the installation of new windows and mechanical heat-recovery ventilation system (PH-S4). All employed building components and construction materials are cost-effective and already available in the New Zealand market. Construction and installation techniques are simple, rapid (mainly add-on non-structural interventions) and common practice in this country.

To further sustain the cost-effectiveness and practicality of the proposed model, the packages are designed either to not require building consent (PH-S1 and $\mathrm{PH}-\mathrm{S} 2)$ or to ease the consenting process (PH-S3 and PH-S4) through the use of standardised components, details and installation methods that may be complemented with pre-compiled documentation. This is of particular relevance in New Zealand as it is aligned with the principles behind the peculiar regulatory framework that, for the consenting process, includes owner-builder (DIYers) exemptions from the 2004 introduced Licensed Building Practitioners Scheme [52].

\subsection{Thermal Modelling and Calculation with Passive House Planning Package}

The retrofit packages are designed to achieve progressive improvements of the envelope's thermal performance and airtightness up to the EnerPHit standard for warm-temperate climates (heating demand $=20 \mathrm{kWh} /\left(\mathrm{m}^{2} \mathrm{a}\right)$ and air permeability rate $\left.\mathrm{n}_{50}<1.0 \mathrm{~h}^{-1}\right)$. For thermal simulation, a "base case" was defined to represent the condition of the house as originally built, without insulation. Four cumulative upgrade levels were then modelled, each including all the interventions of the levels before it. In addition the house was modelled for the current situation (i.e., with the insulation Basic Package, thus labelled SH-BP) and to comply with the current Building Code (SH-NZBC). Simulation models were validated using data from environmental parameter measurements. Air infiltration levels were estimated according to previous studies undertaken by BRANZ [53,54] and to match EnerPHit requirements. To meet the standard, mechanical ventilation with heat recovery (MHRV) was introduced only in the final package (PH-S4).

Preliminary estimates of heat losses and space heating demands were made for the various upgrade options using the computer thermal simulation program Virtual Environment [51]. This helped verify 
the technical and economic feasibility of the proposed interventions, and the magnitude of associated energy savings. On this basis, in the next phase of the study, refined retrofit packages were tested using the Passive House Planning Package (PHPP), the Excel spreadsheet-based design tool specifically developed by PHI to assist architects and designers plan and verify Passive Houses towards certification. It calculates building components' U-values, heating, cooling and primary energy demand, ventilation rates for comfort as well as the risk of overheating in the warmer season. Furthermore, it compiles climate data from many locations worldwide, including Auckland and other main centres in New Zealand. Validated with dynamic simulation tools as well as with measured data, the PHPP energy balance module has proven to be surprisingly precise, calculating the energy balances of a building to an accuracy of $\pm 0.5 \mathrm{kWh}$.

The specific tool embedded in PHPP for calculation of $U$-values allowed a more detailed exploration of individual building component assemblies, taking into account specific construction details and locally available products. To achieve the thermal performance required by the EnerPHit standard (PH-S4), the following insulation options were selected: $190 \mathrm{~mm}$ polyester insulation in the attic space between and above ceiling joists $\left(R\right.$-value $\left.=4.55 \mathrm{~m}^{2} \mathrm{~K} / \mathrm{W}\right) ; 125 \mathrm{~mm}$ glasswool insulation under the floor between joists and $45 \mathrm{~mm}$ EPS between bearers $\left(R\right.$-value $\left.=4.18 \mathrm{~m}^{2} \mathrm{~K} / \mathrm{W}\right) ; 100 \mathrm{~mm}$ glasswool insulation between studs plus $45 \mathrm{~mm}$ of the same material between battens in the service cavity $\left(R\right.$-value $\left.=3.20 \mathrm{~m}^{2} \mathrm{~K} / \mathrm{W}\right)$; low-e, double-glazing timber windows filled with $\operatorname{argon}$ gas $\left(R\right.$-value $\left.=0.73 \mathrm{~m}^{2} \mathrm{~K} / \mathrm{W}\right)($ Table 1$)$.

Table 1. Upgrade levels, including a summary of $R$-values $\left(\mathrm{m}^{2} \mathrm{~K} / \mathrm{W}\right)$ used for each element of the building fabric for PHPP calculation.

\begin{tabular}{|c|c|c|c|c|c|c|}
\hline Upgrade & Insulation & $\begin{array}{l}\text { Ceiling } \\
\mathbf{m}^{2} \mathbf{K} / \mathbf{W}\end{array}$ & $\begin{array}{c}\text { Floor } \\
\mathbf{m}^{2} \mathbf{K} / \mathbf{W}\end{array}$ & $\begin{array}{c}\text { Walls } \\
\mathbf{m}^{2} \mathbf{K} / \mathbf{W}\end{array}$ & $\begin{array}{l}\text { Window } \\
\mathbf{m}^{2} \mathbf{K} / \mathbf{W}\end{array}$ & $\begin{array}{c}\text { Airtightness } \\
\left(n_{50}\right) \mathbf{h}^{-1}\end{array}$ \\
\hline Base Case & House as built (no insulation) & 0.27 & 0.74 & 0.60 & 0.22 & 20 \\
\hline PH-S1 & $\begin{array}{l}\text { Ceiling insulation } \\
100+90 \mathrm{~mm} \text { polyester between and above joists }\end{array}$ & 4.55 & 0.74 & 0.60 & 0.22 & 20 \\
\hline PH-S2 & $\begin{array}{l}\text { As PH-S1 + Floor insulation } \\
125 \mathrm{~mm} \text { glasswool between joists }+40 \text { EPS } \\
\text { between bearers }\end{array}$ & 4.55 & 4.18 & 0.60 & 0.22 & 20 \\
\hline $\mathrm{PH}-\mathrm{S} 3$ & $\begin{array}{l}\text { As PH-S2 + Wall insulation } \\
145 \mathrm{~mm} \text { glasswool between studs and battens }\end{array}$ & 4.55 & 4.18 & 3.20 & 0.22 & 6.5 \\
\hline PH-S4 & $\begin{array}{l}\text { As PH-S3 + Windows upgrade and airtightness } \\
\text { low-e, argon filled double glazing timber windows }\end{array}$ & 4.55 & 4.18 & 3.20 & 0.73 & 1 \\
\hline SH-BP & $\begin{array}{l}\text { SH insulated with basic package (as-it-is) } \\
50 \mathrm{~mm} \text { polyester under floor }+150 \mathrm{~mm} \text { above ceiling }\end{array}$ & 2.42 & 1.73 & 0.60 & 0.22 & 20 \\
\hline SH-NZBC & House to comply with NZBC & 2.90 & 1.30 & 1.90 & 0.26 & 6.5 \\
\hline
\end{tabular}

For this study the new PHPP 9 was used, which allows the direct comparison of different variants, together with their economic evaluation. Additional retrofit options were then tested to verify the specific impact of airtightness, mechanical versus natural ventilation and window performance. The aim of this investigation was to assess under what insulation, ventilation and airtightness conditions the EnerPHit requirements could be met, thus, exploring alternative and affordable solutions to overcome constraints imposed by the existing construction. 


\section{Results and Discussion}

Overall results of PHPP calculation confirm the impact on energy savings of different insulation (ceiling, floor, walls and windows) and airtightness improvements that was found with VE thermal modelling - assuming constant indoor thermal comfort conditions associated with air temperature equal to $20^{\circ} \mathrm{C}$. However, the heating demand of the various options tested is higher, due to the different nature of the two tools and slightly different boundaries conditions (e.g., climate data, treated floor area and ventilation schedule). Furthermore, PHPP provides more detailed calculations of heat losses, including the effect of thermal bridges, natural ventilation and solar gains according to surrounding shading elements.

Figure 5 shows specific annual heating demand $\left[\mathrm{kWh} /\left(\mathrm{m}^{2} \mathrm{a}\right)\right]$ and overheating risk [\% of time] for each of the upgrade scenarios calculated with PHPP. The graph illustrates how improvements from the uninsulated house (Base Case) to one that complies with NZBC reduce heating demand by $74 \%$. This result however can be used as a reference only, because old, draughty houses are not usually evenly heated to reach comfortable indoor temperatures-while new Code-compliant houses should be. A more significant result is that, by improving insulation of ceiling, floor and external walls in the path to meet the EnerPHit standard (PH-S3) [50], annual heating demand drops below that of the Code-compliant house SH-NZBC (78 versus $81.4 \mathrm{kWh} /\left(\mathrm{m}^{2} \mathrm{a}\right)$ ) - using for calculation the same airtightness $\left(n_{50}\right)$ of $6.5 \mathrm{~h}^{-1}$, the average value for new construction according to BRANZ [54].

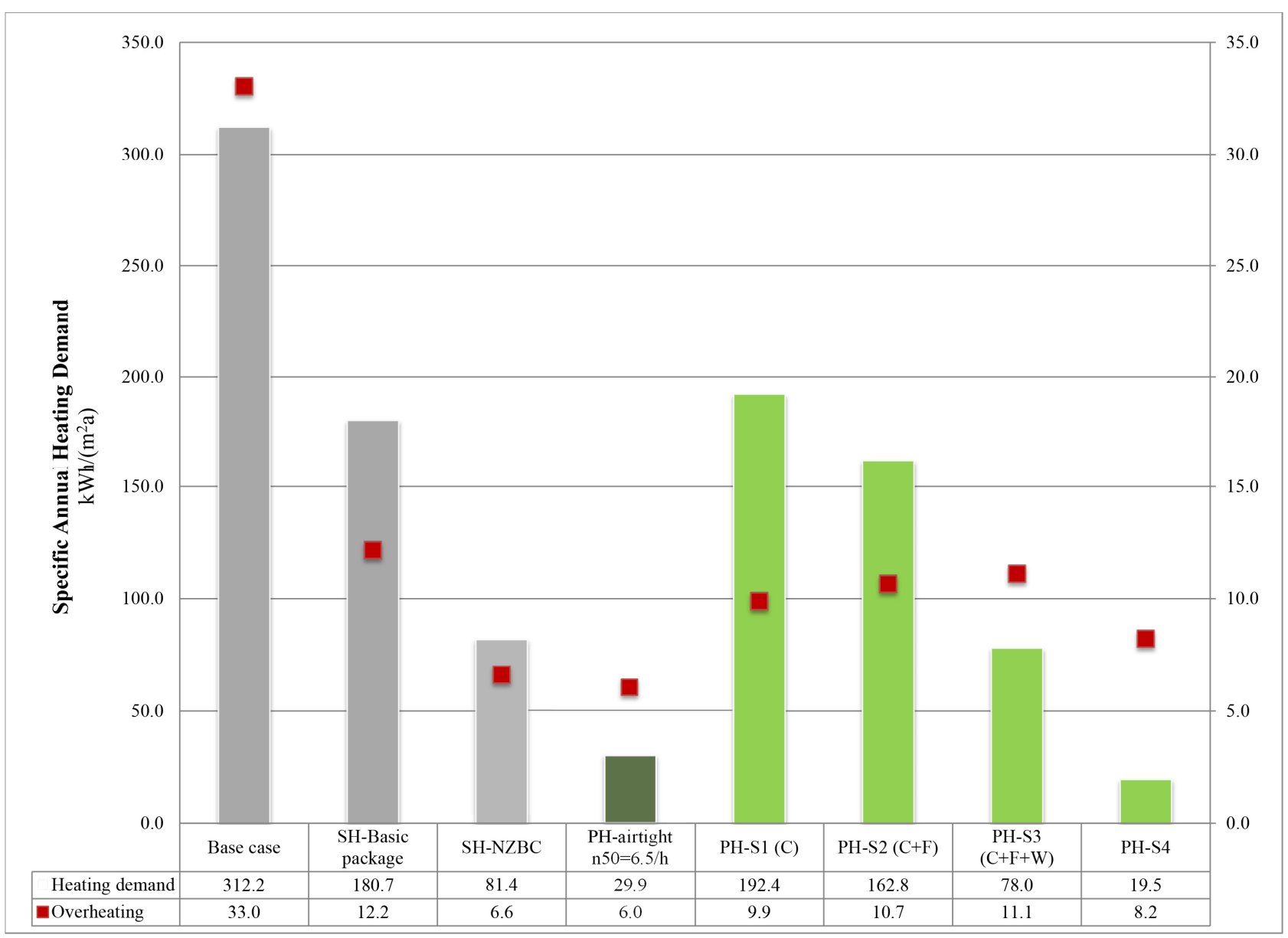

Figure 5. Comparison of specific annual heating demands $\left(\mathrm{kWh} /\left(\mathrm{m}^{2} \mathrm{a}\right)\right)$ and overheating time $(\%)$ of the base case and different retrofitting packages. 
The successive retrofit package PH-S4, with additional interventions to achieve the EnerPHit standard, is essential for reducing heating demand, enhancing indoor comfort and moisture control. New windows $\left(R\right.$-value $\left.=0.73 \mathrm{~m}^{2} \mathrm{~K} / \mathrm{W}\right)$ and overall air permeability rate $n_{50}$ equal to $1.0 \mathrm{~h}^{-1}$, reduce heating demand further, to one quarter (from 78 to $19.5 \mathrm{kWh} /\left(\mathrm{m}^{2} \mathrm{a}\right)$ ), while assuring a constant comfortable indoor temperature of $20^{\circ} \mathrm{C}$. Compared to the Code-compliant house (SH-NZBC), this package produces a marginal increase in overheating risk (due to improved airtightness and reduced heat losses through the envelope), although still below the $10 \%$ limit. The residual discomfort issues could be easily avoided by employing more effective window shading (such as external shutters or blinds) or selective glazing.

Other relevant results emerge from the evaluation of the initial packages' implementation: the first step (PH-S1) confirms the importance of ceiling insulation not only in terms of energy savings (with $38 \%$ heat demand reduction) but also for reducing the risk of overheating. The additional floor insulation in step 2 (PH-S2) has a lower impact on heating demand (15\% reduction) and, decreasing heat loss through the floor in summer, slightly increases the overheating risk. The amount of insulation installed under the floor is excessive for achieving comfortable surface temperatures, but is indispensable to attain the envelope's performance required to meet the standard, as it compensates for the limited amount of insulation that can be accommodated in the wall construction.

Overall, results also prove the positive impact on heating demand reduction of two factors often neglected by the common retrofit practice in New Zealand: wall insulation and air infiltration. This becomes evident through the analysis of outward and inward flows (losses and gains) through the envelope, shown in Figures 6 and 7, which provide details of benefits from each intervention. The comparison of the heat flow break-down of the existing house (SH-BP) and that meeting the NZBC requirements (SH-NZBC) shows a significant reduction of heating demand due to new windows, improved airtightness ( $n_{50}$ drops from 20 to $6.5 \mathrm{~h}^{-1}$ ) and wall insulation; the latter proves to have the greatest impact ( $54 \%$ of the reduction).

U-values input in the calculation can be achieved using different building components and mechanical ventilation solutions available in New Zealand, taking into consideration technologies compatible with the country's construction practice; results show that the heating demand requirements of the EnerPHit standard can theoretically be achieved. However, given the extremely low energy consumption involved, performance could be affected by thermal bridging and airtightness issues. Further research is required to develop thermal bridge-free construction details and effective solutions for a continuous airtight envelope. Indeed, while insulation can easily be installed in existing houses to guarantee the necessary thermal performance of the envelope, achieving levels of airtightness required by the EnerPHit standard can be challenging, due to construction and preservation issues. Deep retrofit interventions, including floor and ceiling replacement as well as new internal partitions, offer the best opportunity to realise a continuous airtight layer inside the timber structure of the existing envelope. Airtight layers (oriented strand board, plywood boards or vapour control membranes) can be installed in the flooring between joists and finishing, in the external wall between the existing timber structure and the new service cavity (to be added inside for accommodating additional insulation and reducing thermal bridges), and in the ceiling below the existing joists. All joints of floor, wall and ceiling airtight layers must be tightly sealed. Achieving the required airtightness levels can be challenging in retrofit interventions where existing floor, ceiling, internal load bearing walls and partitions are maintained in 
place, as the additional airtight layer added on top of existing floor, wall and ceiling surfaces is interrupted by the structure of each internal partition, and so is difficult to seal. Airtightness though, is key to reducing heating demand, as PHPP calculations show that, in the final package (PH-S4) shifting $n_{50}$ from $1 \mathrm{~h}^{-1}$ (EnerPHit limit) to $8 \mathrm{~h}^{-1}$ (value estimated for contemporary retrofitted Auckland houses), results in $60 \%$ heating demand increase. As shown in Figure 7, even increasing $n_{50}$ just to $6.5 \mathrm{~h}^{-1}$ (PH-S4*), which is the same airtightness of SH-NZBC, increases specific ventilation losses from 5.1 to $19.7 \mathrm{kWh} /\left(\mathrm{m}^{2} \mathrm{a}\right)$ - higher than the specific annual heating demand of $\mathrm{PH}-\mathrm{S} 4$ - and heating demand to $29.9 \mathrm{kWh} /\left(\mathrm{m}^{2} \mathrm{a}\right)$.

Experimental research is required to evaluate the achievability of the desired infiltration rate in either intervention (also considering cost issues) since there are no examples in New Zealand of retrofitted houses to EnerPHit standard. This should also include studies of technological and economic feasibility to identify the achievable airtight levels and, if lower than required by the standard, to evaluate how to compensate for the increased heating demand with either additional insulation or higher performance windows (without compromising indoor comfort and building integrity).

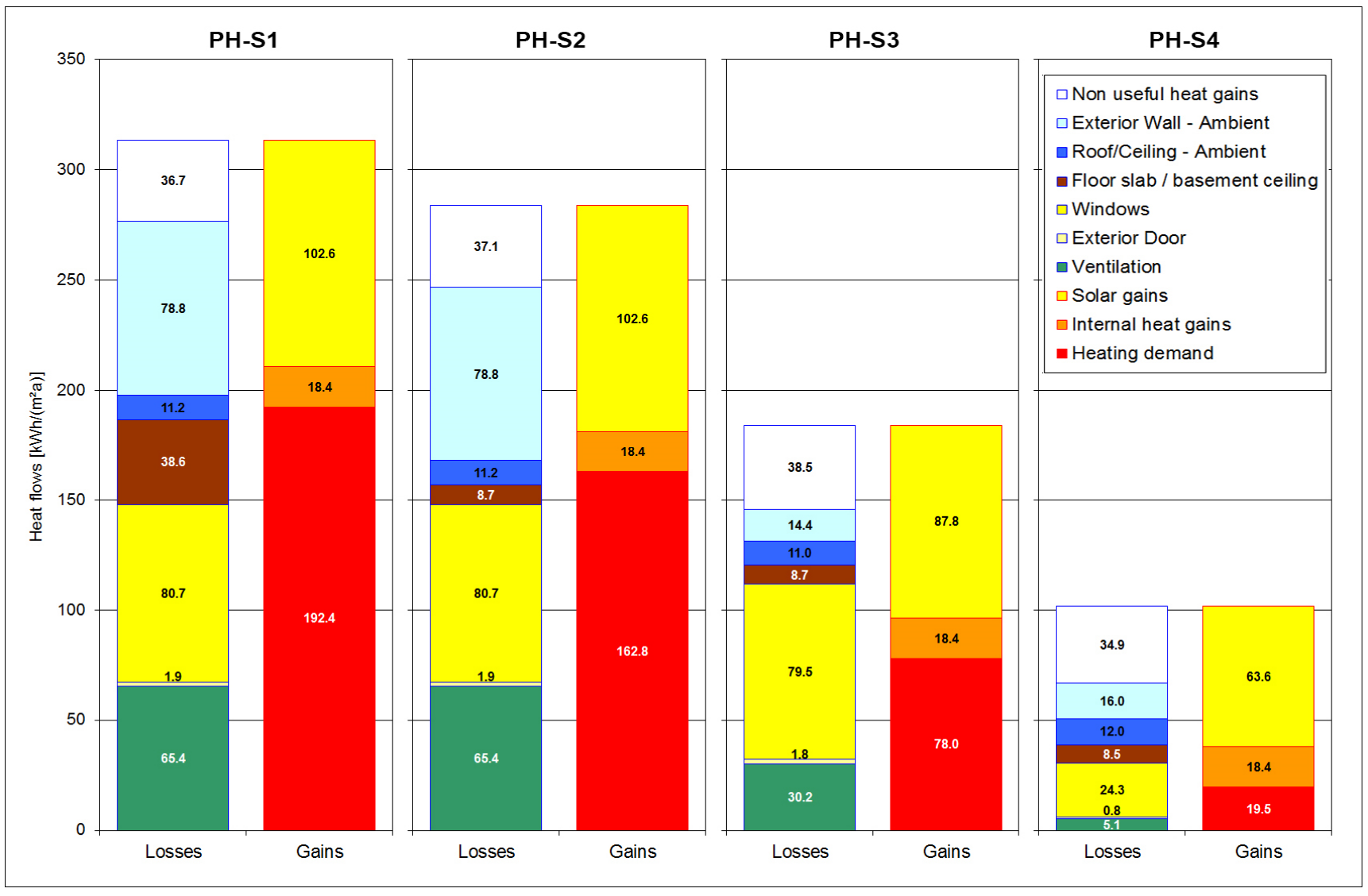

Figure 6. Comparison of heat flows (losses and gains) of the four incremental retrofit packages to meet the EnerPHit standard calculated with PHPP. 

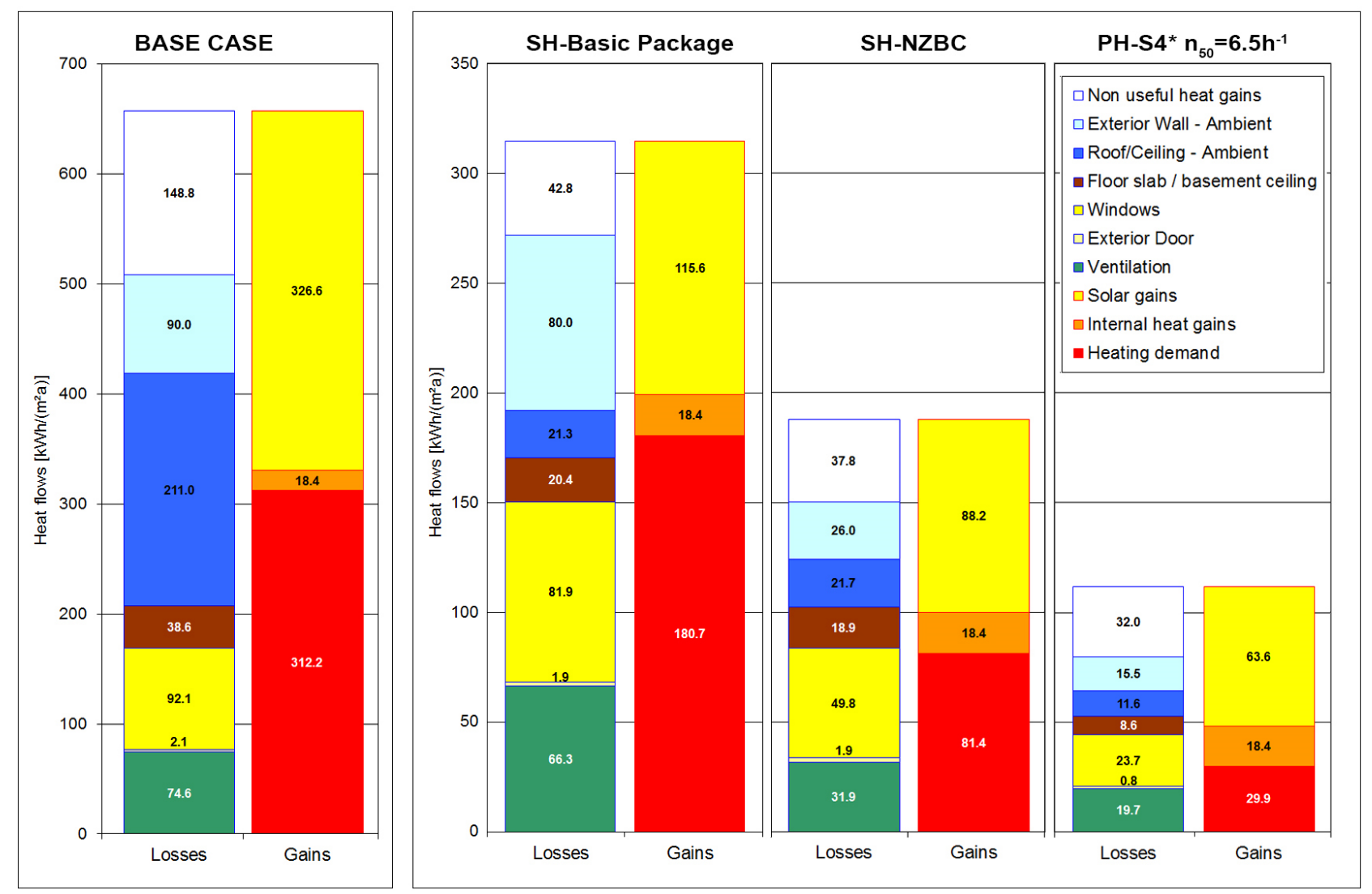

Figure 7. Heat flows (losses and gains) of the Base Case (axis maximum value: $\left.700 \mathrm{kWh} /\left(\mathrm{m}^{2} \mathrm{a}\right)\right)$ and comparison of heat flows (losses and gains) of SH-BP, SH-NZBC and PH-S4* (axis maximum value: $350 \mathrm{kWh} /\left(\mathrm{m}^{2} \mathrm{a}\right)$ ) calculated with PHPP.

The comparative analysis of different ventilation systems showed the effect of MHRV on heat demand and summer comfort. The impact of airtightness and ventilation is evident when comparing the heat flow breakdown of PH-S3 and PH-S4 (Figure 6), where the installation of MHRV and new double-glazed timber windows halves ventilation losses. In winter, a balanced MHRV proves to be key to maintaining heating demand below the limit of $20 \mathrm{kWh} /\left(\mathrm{m}^{2} \mathrm{a}\right)$, as with natural ventilation it would increase from 19.5 to $28.1 \mathrm{kWh} /\left(\mathrm{m}^{2} \mathrm{a}\right)$. Summer overheating was identified as a potential issue for the existing house, which has its largest windows exposed to the western afternoon sun. PHPP calculations show that heat recovery only provides a small reduction of the overheating percentage. Thus, overall energy consumption could be reduced (and the New Zealanders' propensity for indoor/outdoor flow favoured) by coupling winter use of the balanced heat recovery ventilation system with increased (when compared to the actual schedule provided by the occupants) summer natural ventilation. Increasing natural ventilation in summer only reduces the percentage of overheating during the warmest months, given the minimal air temperature difference between inside and outside, but is insufficient for night cooling of lightweight building structures. To achieve better indoor comfort conditions, a suitable option would be to utilise mechanical ventilation in summer (activated by temperature or humidity sensors) without heat recovery.

Costing the upgrades and undertaking a cost-benefit analysis of the investments over a long-term period would enable a full assessment to be made for the upgrade of the national stock to EnerPHit standard. The complete retrofit intervention in the cost-benefit analysis should include a fully insulated 
and airtight envelope, high performance windows with external shadings to prevent overheating in summer, and supplemental space heating (normally distributed through the low-volume MHRV system). As 1940-1960s standalone houses represent an important portion of the national housing stock, results of this analysis can be extrapolated to different climate zones to estimate levels of insulation required and associated costs. Previous research [55] has provided some indicative costing for upgrading state houses to NZBC requirements in different climate zones: as Passive Houses require extra levels of insulation, airtightness and higher performance windows, this initial estimate needs to be increased. Design optimization/standardization and product availability on the New Zealand market are possible ways to overcome expected barriers to retrofitting to EnerPhit standard.

\section{Conclusions}

The research discussed in this paper challenges the current New Zealand retrofit practice that, driven mainly by financial return, disregards social, cultural and environmental matters lying beyond regulatory prescriptions and engenders severe problems of health, energy waste and building decay. These issues are of primary importance when dealing with pre-1978 state housing, still largely occupied by the most economically vulnerable part of the population.

In consideration of the World Health Organisation [9] suggestion that, for long-term solutions, financial support to households for fuel expenses needs to be subordinated to housing energy upgrade, this study argues that subsidies should be streamed towards achieving economically feasible nearly zero-energy buildings, to detach living conditions from the risks presented by the use of unreliable heating sources and exacerbation of financial constraints. This goal, for the existing Auckland building stock, can be achieved through retrofitting interventions that meet the EnerPHit standard.

This study uses a holistic retrofit approach to develop a retrofitting strategy based on incremental interventions that are defined, prioritised, evaluated and optimised, using a representative case-study; a 1950s state house located in Auckland. The use of thermal modelling and PHPP calculation allows assessing the impact of different factors — such as wall insulation, ventilation mode, and air infiltration — on the building energy performance.

The assessment of a basic retrofit package - only including ceiling and floor insulation ( $\mathrm{SH}-\mathrm{BP}$ and $\mathrm{PH}-\mathrm{S} 2$ ) - shows that the common interventions supported by governmental subsidies are not sufficient to effectively reduce energy consumption. Through the comparative evaluation of the results of different retrofit interventions modelled with the PHPP software, the study illustrates how effective results can be achieved with comprehensive retrofit interventions that combine insulation and airtightness of the whole building envelope with controlled ventilation.

Detailed calculations with PHPP show that, given the mild climate of the region, the specific insulation requirements of the EnerPHit standard can be achieved using existing technology and construction materials available on the local market. However, airtightness represents the main challenge and further empirical research is needed to develop technologically and economically viable retrofit details for a thermal bridge-free and airtight envelope.

Overall, the approach adopted in this study is also consistent with the on-going research project EuroPHit [56], which aims to establish a certification scheme for stepwise retrofit with Passive House components. In cases of step-by-step deep retrofit, a comprehensive renovation plan, covering both 
present and future steps, can help ensure the integrity of the building throughout the whole process. This scheme though, and the European EnerPHit standard, were developed for application in countries with cool-temperate climates. International criteria for Passive House components and the associated EnerPHit certification, currently under development, are likely to make certification in New Zealand more challenging by decreasing heating demand limits according to warmer climates. However, as the retrofit packages proposed in the study were developed by selecting the most cost effective components, there seems to be scope for further improvements of envelope performance in order to match future requirements.

Lastly, it is important to remark that New Zealand state housing retrofit is case-specific, despite the standardised nature of these buildings, and evolutive, since the achievement of high performance-based standards, such as EnerPHit, benefits from the steady improvement of construction technology. This will be taken into account in the future phases of this research, which will shift from theory and calculation to practice: with the implementation of the identified retrofit strategy, this study aims to prove that this approach to retrofitting is not only technically feasible and economically viable, but also socially and environmentally desirable, thus encouraging essential changes in New Zealand practice.

\section{Acknowledgments}

The authors acknowledge the financial support from the University of Auckland. They also acknowledge the support of Housing New Zealand Corporation. Special thanks go to Passivhaus Institut for granting access to their databases, as well as to unpublished documents and tools.

\section{Author Contributions}

The co-authors both contributed equally to this research project and the writing and review of this article.

\section{Conflicts of Interest}

The authors declare no conflict of interest.

\section{References}

1. International Energy Agency. Available online: https://www.iea.org/aboutus/faqs/energyefficiency/ (accessed on 28 April 2014).

2. Preservation Green Lab. The Greenest Building: Quantifying the Environmental Value of Building Reuse; National Trust for Historic Preservation: Seattle, WA, USA, 2011.

3. Poot, J. Building activity brings many benefits for NZ. Build Magazine 2011, 125, 30-31.

4. Page, I.C.; Fung, J. Housing Life Cycle and Sustainability. BRANZ Study Report 214; Building Research Association New Zealand: Porirua, New Zealand, 2008.

5. Department of Building and Housing. New Zealand Housing Report 2009/2010: Structure, Pressures and Issues; Department of Building and Housing: Wellington, New Zealand, 2010.

6. Auckland Council. The Draft Auckland Plan; Auckland Council: Auckland, New Zealand, 2011. 
7. Building Research Association New Zealand. Building a Better New Zealand. Annual Review 2014; Building Research Association New Zealand: Porirua, New Zealand, 2014.

8. Isaacs, N.; Camilleri, M.; French, L.; Pollard, A.; Saville-Smith, K.; Fraser, R.; Rossouw, P.; Jowett, J. Energy Use in New Zealand Households: Report on the Year 10 Analysis for the Household Energy End-use Project (HEEP). BRANZ Study Report 155; Building Research Association New Zealand: Porirua, New Zealand, 2006.

9. World Health Organization. Regional Office for Europe. Housing, Energy and Thermal Comfort; World Health Organization: Copenhagen, Denmark, 2007.

10. Pattemore, P.K.; Ellison-Loschmann, L.; Asher, M.I.; Barry, D.M.J.; Clayton, T.O.; Crane, J.; D’Souza, W.J.; Ellwood, P.; Ford, R.P.K.; Mackay, R.J.; et al. Asthma prevalence in European, Maori, and Pacific children in New Zealand: ISAAC study. PediatrPulmonol 2004, 37, 433-442.

11. Regional Growth Forum. Auckland Regional Affordable Housing Strategy; Auckland Regional Council: Auckland, New Zealand, 2003.

12. Olssen, A.; McDonald, H.; Grimes, A.; Stillman, S. A State Housing Database: 1993-2009; Motu Working Paper; Motu Economic and Public Policy Research: Wellington, New Zealand, 2010.

13. Howden-Chapman, P.L.; Carroll, P. Housing \& Health: Research, Policy and Innovation; Steele Roberts: Wellington, New Zealand, 2004.

14. Page, I.; Ryan, V. It Takes All Types: A Typology of New Zealand Housing Stock Retrofits. In Innovation and Transformation, Proceeding of the SB10 Conference, Wellington, New Zealand, 26-28 May 2010.

15. Passive House Institute. EnerPHit: Certification Criteria for Retrofits; Passive House Institute: Darmstadt, Germany, 2012.

16. Schrader, B. We Call It Home: A History of State Housing in New Zealand; Reed: Auckland, New Zealand, 2005.

17. Ferguson, G. Building the New Zealand Dream; Dunmore: Palmerston North, New Zealand, 1994.

18. Wakefield, E.G. A View of the Art of Colonization, with Present Reference to the British Empire; J. Parker: London, UK, 1849.

19. Holden, H.C. Summary; Department of Internal Affairs: Wellington, New Zealand, 1959.

20. Manfredini, M.; Leardini, P. Eco-Retrofitting Analysis, Strategies and Pilot Project for State Housing in Auckland, New Zealand. In Proceedings of the Retrofit 2012 Academic Conference, Manchester, UK, 24-26 January 2012.

21. Pevsner, N. The Ingratiating Chaos. In Pevsner on Art and Architecture: The Radio Talks; Games, S., Ed.; Methuen: London, UK, 2002; pp. 259-264.

22. Organisation for Economic Co-Operation and Development (OECD). How's Life? 2013: Measuring Well-Being; OECD Publishing: Paris, France, 2013.

23. Statistics New Zealand. Household Economic Survey (Income): Year Ended June 2014. Available online: http://www.stats.govt.nz/browse_for_stats/people_and_communities/Households/Household EconomicSurvey_HOTPYeJun14/Commentary.aspx\#housing (accessed on 10 December 2014).

24. Demographia. 10th Annual, Demographia International Housing Affordability Survey: 2014. Ratings for Metropolitan Markets; Demographia: Belleville, IL, USA, 2013.

25. Building Research Association New Zealand. Auckland Housing Forecasts and the Unitary Plan; Building Research Association New Zealand: Porirua, New Zealand, 2013. 
26. Ingerson, J. Where and What Are Investors Buying? Westpac REDnews, 6 October 2014. Available online: http://www.westpac.co.nz/rednews/property/where-and-what-are-investors-buying/ (accessed on 10 December 2014).

27. Buckett, N.R.; Marston, N.J.; Saville-Smith, K.; Jowett, J.H.; Jones, M.S. BRANZ Study Report SR 240-Preliminary BRANZ 2010 House Condition Survey Report-Second Edition; Building Research Association New Zealand: Porirua, New Zealand, 2011.

28. Energy Efficiency and Conservation Authority and Ministry of the Environment. National Energy Efficiency and Conservation Strategy. Towards a Sustainable Energy Future; Energy Efficiency and Conservation Authority and Ministry of the Environment: Wellington, New Zealand, 2001.

29. New Zealand Government. National Energy Efficiency and Conservation Strategy. Making it Happen; New Zealand Government: Wellington, New Zealand, 2007.

30. Department of Building and Housing. Compliance Document for New Zealand Building Code Clause H1 Energy Efficiency, 3rd ed.; New Zealand Government: Wellington, New Zealand, 2011.

31. Department of Building and Housing. Compliance Document for New Zealand Building Code Clause G5 Interior Environment; New Zealand Government: Wellington, New Zealand, 2011.

32. McChesney, I.; Cox-Smith, I.; Amitrano, L. Thermal Insulation in New Zealand Homes: A Status Report; Beacon Pathway Limited: Auckland, New Zealand, 2008; pp. 52-53.

33. Page, I. Cost Benefits of Housing Retrofits. In Proceeding of the SB10 Conference Innovation and Transformation, Wellington, New Zealand, 26-28 May 2010.

34. Howden-Chapman, P.L.; Chapman, R.; Viggers, H.; O’Dea, D.; Kennedy, M. Retrofitting houses with insulation: A cost-benefit analysis of a randomized community trial. J. Epidemiol. Community Health 2009, 63, 271-277.

35. Elkink, A. Renovate 1940-1960s; Building Research Association New Zealand: Porirua, New Zealand, 2011.

36. Firth, C. State Housing in New Zealand; Ministry of Work: Wellington, New Zealand, 1949.

37. Brien, R.M.; Winsome, D.R. Investigation into Causes and Control of Moulds in State Houses; Department of Scientific and Industrial Research: Wellington, New Zealand, 1944.

38. Marsden, E. State House-Erection at Dominion Physical Laboratory; Department of Scientific and Industrial Research: Wellington, New Zealand, 1946.

39. Lloyd, C.R. Fuel poverty in New Zealand. Soc. Policy J. N. Z. 2006, 27, 142-155.

40. Clinton, J.; Mahony, F.; Irvine, R.; Bullen, C.; Kearns, R. The Healthy Housing Programme: Report of the Outcomes Evaluation; Housing New Zealand Corporation: Wellington, New Zealand, 2006.

41. Grimes, A.; Denne, T.; Howden-Chapman, P.; Arnold, R.; Telfar-Barnard, L.; Preval, N.; Young, C. Cost Benefit Analysis of the Warm Up New Zealand: Heat Smart Programme; Ministry of Economic Development: Wellington, New Zealand, 2012.

42. Ebel, W.; Feist, W.; Kaufmann, B. Economy and Financing of Efficiency: New Buildings, Renovation and Step by Step Renovation. In Proceedings of the 18th International Passive House Conference 2014, Aachen, Germany, 25-26 April 2014; Passive House Institute: Darmstadt, Germany, 2014; pp. 145-154.

43. Guidance on Building Code Compliance for Retrofitting Insulation in External Walls. Available online: http://www.dbh.govt.nz/retrofitting-insulation-guidance\#fid20 (accessed on 10 December 2014). 
44. Leardini, P.; Rosemeier, K.; Ong, A. Ventilation's Pivotal Role for Indoor Air Quality of Houses in New Zealand. In Proceedings of the Healthy Buildings 2012, Brisbane, Australia, 8-12 July 2012.

45. American Society of Heating, Refrigerating, and Air-Conditioning Engineers. ASHRAE Standard 55-2010: Thermal Environmental Conditions for Human Occupancy; American Society of Heating, Refrigerating, and Air-Conditioning Engineers: Atlanta, GA, USA, 2010.

46. Ministry of Business, Innovation and Employment. Acceptable Solutions and Verification Methods for New Zealand Building Code Clause G4 Ventilation, 3rd ed.; New Zealand Government: Wellington, New Zealand, 2014.

47. Leardini, P.; de Groot, H. Indoor Air Quality and Health in New Zealand's Traditional Homes. In Proceedings of the 44th Annual Conference of the Australian and NZ Architectural Science Association, Auckland, New Zealand, 24-26 November 2010.

48. Passive House Institute. Certified Passive House-Certification Criteria for Residential Passive House Buildings; Passive House Institute: Darmstadt, Germany, 2013.

49. The Passive House-Definition. Available online: http://passipedia.passiv.de/passipedia_en/basics/ the_passive_house_-_definition (accessed on 14 April 2014).

50. Bastian, Z. International EnerPHit Certification Criteria for Energy Retrofit with Passive House Components. In Proceedings of the 18th International Passive House Conference 2014, Aachen, Germany, 25-26 April 2014; Passive House Institute: Darmstadt, Germany, 2014; pp. 615-624.

51. Leardini, P.M.; Manfredini, M.; Callau, M. Energy Upgrade to Passive House Standard for Historic Public Housing in New Zealand. In Proceedings of the 49th AICARR International Conference, Rome, Italy, 26-28 February 2014.

52. The Building Act 2004; Brookers: Wellington, New Zealand, 2004.

53. Bassett, M.R. Building Site Measurements for Predicting Air Infiltration Rates. In ASTM Special Technical Publication 904; ASTM: Philadelphia, PA, USA, 1986; pp. 365-383.

54. McNeil, S.; Quaglia, L.; Bassett, M.; Cunningham, M.; Overton, G.; Plagmann, M.; Boulic, M.; Leardini, P.; Rosemeier, K.; Smith, I. Trends in Airtightness of New Zealand Homes. In Proceedings of the 19th International Congress of Biometeorology Conference, Auckland, New Zealand, 5-9 December 2011.

55. Lloyd, C.R.; Callau, M.F.; Bishop, T.; Smith, I.J. The efficacy of an energy efficient upgrade program in New Zealand. Energy and Buildings 2008, 40, 1228-1239.

56. EuroPHit. Available online: http://europhit.eu/project (accessed on 10 December 2014).

(C) 2015 by the authors; licensee MDPI, Basel, Switzerland. This article is an open access article distributed under the terms and conditions of the Creative Commons Attribution license (http://creativecommons.org/licenses/by/4.0/). 